DOI: $10.17516 / 1997-1370-0593$

УДК 314.742

\title{
Host Society and Migrants: Searching for the Languages of Mutual Description
}

\author{
Konstantin V. Grigoricheva,b and Natalia P. Koptsevac* \\ arkutsk State University \\ Irkutsk, Russian Federation \\ ${ }^{b}$ National Research Tomsk State University \\ Tomsk, Russian Federation \\ cSiberian Federal University \\ Krasnoyarsk, Russian Federation
}

Received 15.03.2020, received in revised form 30.04.2020, accepted 12.05.2020

\begin{abstract}
The article provides a selection of studies on the problem of developing languages for the mutual description of migrants and the host society. The authors consider the problem, on the one hand, through the prism of heterogeneity of the language for describing migrants in the host society, and on the other, through the absence of legitimate representatives of migrants representing them in the dialogue with the Russian society. It offers a point of view on the reasons for the dominance of ethnic discourse in the description of migrants and the migration situation, and wide pluralism in the use of ethnic categories in describing migration. It is shown that migrants do not participate in the development of rhetoric of organisations recognised by the authorities as their legitimate representatives. The article raises the question about the formation of new representatives of migrant groups, whose legitimacy is based not on powers delegated by the authorities, but on recognition by horizontal communities. It is assumed that, on the basis of the network representations, a mechanism is being formed for the humanisation of the image of migrants through the return of subjectivity in communication with the host society.
\end{abstract}

Keywords: languages of description, host society, migrants, ethnicity, horizontal networks, YouTube.

The research was supported by the grant from the Russian Science Foundation No. 1818-00293.

Research area: sociological sciences.

Citation: Grigorichev, K.V., Koptseva, N.P. (2020). Host society and migrants: searching for the languages of mutual description. J. Sib. Fed. Univ. Humanit. Soc. Sci., 13(5), 612-622. DOI: 10.17516/1997-13700593.

\footnotetext{
(C) Siberian Federal University. All rights reserved

* Corresponding author E-mail address: grigoritchev@yandex.ru, decanka@mail.ru ORCID: 0000-0002-5256-5658 (Grigorichev); 0000-0003-3910-7991 (Koptseva)
} 
Despite the uneven economic development, numerous crises and recessions following periods of rapid growth, Russia is confidently becoming a country of migrants. Russian society painfully searches for a language of reflections regarding this phenomenon, which is new to it, often through the development of new ones and the reconstruction of old stereotypes and phobias (Dyatlov, 2010). Being the first and, perhaps, inevitable way of reflection on a new phenomenon, they nevertheless sharply pose problems of developing effective communication strategies with migrants and their communities in the host society. In a broader perspective, this communication problem is not only societies and states with migrants, but also the development of languages spoken by a heterogeneous host society about migrants, migrants about the host society, and migrants with migrants and about migrants. It seems to us that this problem lies not so much in the difference of languages, but in the mismatch of problems and discourses.

The distance with a migrant stranger, at the first stages of Russia's inclusion in cross-border migrations embodied at the household level in non-verbal communication strategies, has become less obvious in recent years due to the widespread use of lingua franca strategies, which is Russian as a matter of fact (see, e.g., Grigorichev, Guzey, 2017). The problem of the difference in the languages of describing migrants by different groups of the host society, the lack of consensus in terms, ideas, and images regarding migrants remains less obvious, but the most acute one. The discursive distance between the languages of power, science, media and the street in Russia is often greater and more difficult to overcome than the language barrier between the average person and the migrant. It is significant that the difference between media images and academic ideas about migrants at the end of 2000s (Dyatlov, ed., 2009) and at the end of 2010s (Bryazgina et al., 2019) not only did not decrease, but almost became larger. The inclusion in the structure of the Ministry of Internal Affairs of the Federal Migration Service in 2016 with the closure of public councils working in cooperation with the latter, in fact, eliminated the communica- tion platform between the authorities, the academic community and migrants, which, with varying degrees of success, but still helped to develop a common language.

One of the consequences of the lack of such platforms for communication was the disappearance of migrants and/or their figure representing the communication about migration. In this perspective, it is significant that the vast majority of academic texts devoted to the analysis of the description of migration and migrants focuses on the description of migrants by the host society. The second side, i.e. a participant in the description of migration as a social phenomenon, remains beyond observation and reflection. Euphemistically speaking, the second side of the dialogue is deprived not only of the language, but also, contextually, of the right to have one. The different reality of migration (locals and new comers) fits into the Procrustean bed of the language of one-sided descriptions. Given the heterogeneity of the languages of describing the host society itself, a migrant view of the host society and its interaction with it has almost no chance of being said and heard.

It seems that such a one-sided approach to communication between migrants and the host society is becoming one of the factors in the instability of migrant status in the Russian society. Not only the emergence of new migrants, but also a change in the structure of already familiar migration flows easily turns a migrant-alien, but familiar and necessary, into an absolute stranger. If the former has a place and function that is understandable for the host society in everyday life, then the only explanation for the reason and meaning of the appearance of the latter is 'capture', 'occupation', or at least cultural aggression (Grigorichev, 2018). In this sense not only massive (including academic) texts in connection with the rapid growth of tourist flow from China are quite indicative, but also a Russian (especially non-academic) view of the migration crisis in Europe in 2015-2017.

In this regard, the question remains open not only about the difference in the languages of mutual descriptions of the host society and migrants, but also about whether a development 
of a language for self-description of migrants and their description of host communities occurs. Who and where develops the words and meanings that migrants 'say' about themselves and the host society? Who articulates the migrant view of the migration situation and how is the right to such articulation set, and more broadly, the right to speak on behalf of migrants? Finally, what communication strategies of migrants and the host society are developed in the context of pluralism of the language(s) of the description of migrants in the host society and the uncertainty of the second side of the dialogue?

\section{The language of the host society}

It seems that the specifics of the Russian situation lies not only in the relatively recent inclusion in the logic of world migrations (and indeed cross-border migrations in general), but also in the path dependence of the post-Soviet situation, from the Soviet background, which largely determines the heterogeneity of the language for describing migrations and migrants in the host community. In our opinion, difficulties with seeing eye to eye about the words and meanings of the description of migrants in the Russian society is largely determined by the absence of a cross-border migrant figure (and a migrant in general) in the image of a stranger in the Soviet society. As vividly showed by V.I. Dyatlov, a stranger for the Soviet people "was a 'man from the moon', from another dimension" (Dyatlov, 2010: 124), who did not correlate with everyday life neither as a Friend nor as a Stranger. There was simply no place for a foreigner in it. The giant internal migration organised by the state, suggested other dimensions for description, including the dominant category of the enemy (especially in relation to mass forced migrations), or, on the contrary, the image of a hero (virgin lands, construction of the Baikal-Amur Mainline, Bratsk Hydroelectric Power Station, etc.). Both of them were equally representing a stranger who intrudes into their usual everyday life, but their otherness was not determined by their migration experience.

The first post-Soviet cross-border migrants in Russia turned out to be by no means
Simmel- strangers (Simmel, 2008): another, but necessary, far and close at the same time, performing the most important function for the existence of the host community. Rather, they became strangers in the Bauman sense (Bauman, 2008): bringing chaos and destruction to the familiar world. Appearing in Russian cities and, first of all, in the Russian province, which was not ready for such a massive flow of various strangers, cross-border migrants found themselves outside the sphere of familiar concepts and stable descriptions. The society simply had not enough words and meanings to define them. The important thing here was the exclusion in the Soviet society of the most important function of a stranger - trade. If in Simmel's understanding no one but a stranger can fulfil the function of a tradesman and more broadly a mediator, then in the Soviet society the functions of a stranger are performed by power-distributive functions of the state. Having been forced out onto the periphery of the everyday life, the function of a tradesman-mediator did not leave a place for a stranger in the usual way of life in the Russian society, and especially in a conservative province.

The role of Simmel's stranger, forced out from everyday life, did not exhaust the obvious internal heterogeneity of the Soviet society. The class discourse, despite its obvious dominance, did not exhaust the differences faced by the Soviet ordinary people. Rapid urbanisation has dramatically increased the cultural diversity of urban space already due to multidirectional migration flows, including from the periphery to metropolitan cities and large cities. However, the migration experience did not become the leading marker of the stranger, although in a number of cases it was the experience of spatial movement that became key for determining the stranger (for example, Moscow 'limiters'). It can be assumed that the reason for this was the predominantly organised Soviet migrations, when each inhabitant could become a relocatable resource.

The legal option for describing the stranger becomes the language of ethnography, which recorded intergroup differences through predominantly ethnic discourse, both in the official academic position and, for example, in 
the non-orthodoxal constructions of L.N. Gumilyov. The language of power in many respects was formed precisely on this basis, and partly dates back to the Stalin's "Marxism and the problems of linguistics". It legitimised precisely ethnic categories to describe intergroup differences, which naturally became the language for describing the stranger in the Soviet media. In turn, the Soviet media (newspapers, radio, television) formed the reality of the media, the discourse of which about the stranger was based largely on the ethnic categories. As a result, for the Soviet citizen, the language of ethnicity, together with the language of class differences, became the basis for describing personal experience of contact with the stranger. The strongest Soviet cinematic images of gypsies are quite characteristic in this sense (for example, "Gypsy", 1979, directed by A. Blank), in which the other way of life was interpreted through ethnic images.

It is no coincidence that it is ethnic categories that are widely distributed to describe and attribute certain properties and occupations to rather large groups that have fallen out of the Soviet system of functions and statuses. In most Soviet cities there was the image of the gypsy "pit" - the criminal districts, as a rule, in the "private housing sector", which concentrated not only the criminal, but also non-criminal extralegal practises (for example, the collecting of the "steklotara", i.e. empty glass bottles). Non-state construction teams of "Armenian shabashniks" were known throughout the USSR, in which representatives of Transcaucasia might not constitute a majority. Perhaps the image of a Georgian as a market-trader was just as stable.

The actualisation of ethnicity and the collapse of the Soviet Union dramatically increased the degree of otherness of the ethnically labeled strangers. Along with the set of foreign practices (cultural, economic, linguistic), ethnically different strangers become carriers of a priori mobility, migration experience if not of their own, then of previous generations. Representatives of the 'fraternal peoples', often living in a particular locality of Russia for several generations, becomes visitors, migrants. Migration and adaptation experience, together with ethnicity, become key characteristics of the strangers and, to a large extent, begin to be identified with each other, giving rise to an inverse relationship between migration and ethnicity. It is significant that Russian-speaking migrants from the former Soviet republics to Russia in the first half of the 1990s were described by the host communities through the pseudo-ethnic category 'other Russians' (Vitkovskaya, 1999; Kiseleva, Damberg, 2001; Rotar', 2001): the presence of a migration symbol required ethnic characteristics to describe the group as well.

The emergence of cross-border migrants in Russia has become, first of all, one of the mechanisms for returning the figure and function of a trader to everyday life. This phenomenon required the search for new words and meanings not only to designate new actors, but also their role. Along with building new words and concepts, the old Soviet ideas about the traders called 'torgash' (profiteer), 'meshochnik' (haggler), 'spekulyant' (speculator), were updated. Habitual due to their own experience, or recognisable and borrowed from official history, these words gained new content and meaning, but steadily reproduced negative connotations. The language of ethnic categories, perhaps the only 'legal' categorical apparatus in the Soviet discourse for describing extra-class differences, becomes the generalising language of descriptions for former Soviet and new roles and statuses.

With the development of practices for interacting with them, the Chinese, Tajiks, Uzbeks, and 'Caucasians' acquired important functions for the host community, which smoothly transferred their status of the strangers as an integral part of 'us'. Along with overcoming the distance "We versus Others", the Soviet stereotype of a tradesman as a carrier of 'non-Soviet' values was gradually overcome. It does not seem accidental that in the descriptions of migrants the key feature is not the type of activity, but the migration experience (individual or group) through which the social position is described and attributed. However, their nomination as non-migrant, but ethnic groups continues to dominate the power, media and everyday discourse. According to E.V. Filippo- 
va, this sets "a conceptual framework that can be called an 'ethnic prism' or 'ethnic glasses"” (Filippova, 2019: 202).

This raises the problem of an increasingly acute discrepancy in the understanding of ethnic categories in academic, media, and everyday discourse. Whether it is the spontaneous primordialism of 'expert knowledge', or the cautious constructivism of academic texts by anthropologists, the use of ethnic categories already contextually defines the grouping of descriptions. A constructed or inalienable 'ethnic' identity, a connection with a group for one reason or another, arises here even against the will of the authors. The categorisation here, contrary to Roger Brubaker (Brubaker, 2012: 33), makes grouping, if not in the author's ideas, then in the logic of media reality, where what a person read/saw/heard means more than their own experience (Luhmann, 2005).

On the contrary, ethnically the categories in the description of migrants and migrant groups at the household level have turned less into a tool for determining a group, but into a way for marking acceptable practices of interaction, 'execution' according to E. Goffman (Goffman, 2000), possible and approved in certain situations and no less clearly defined localities. Thus, 'Chineseness' perceived precisely as an ethnic category (especially in the context of spontaneous primordialism of the media), in everyday practice turns out to be a category that describes not a certain group, but the situation, urban locality and the practices which are allowed/approved here. It is noteworthy that the dominance and even the presence of the Chinese themselves is often not a necessary condition for determining a particular city locality (open-air market, store or service) as 'Chinese' (Grigorichev, 2018).

As we can see, ethnic categories in the daily descriptions of migration and migrants do not necessarily imply anchoring of grouping on the basis of ethnic solidarity or similarity of migration experience. However, reproduced in the media and as such falling into the research focus, such definitions can be endowed with 'traditional' meanings for researchers. As a result, the 'Chinese car service' from a specific one in terms of cost, quality and timescales of service becomes an ethnically labeled migrant locality. In other words, the 'ethnic prism' as the dominant language for describing migration and migrants to a large extent turns out to be a question of the meanings invested in the corresponding categories by researchers, authorities, media, and ordinary people, each of which describes different realities using the same words. As a result, the language for describing migrants in the host society turns out to be many languages for describing multiple realities. Herewith, a purely academic discussion about the 'death of the ethnic group theory' (Tishkov, 2016) becomes not only a polemic about connecting the languages of different sciences and scientific generations, but also a purely applied problem of connecting migrant discourses of science, government, media, and everyday life.

\section{The voices of 'migrants': \\ between formal legitimacy \\ and informal approval}

Despite the question posed at the beginning of the article, it would be still an exaggeration to say that no one speaks on behalf of migrants. For about 30 years, national-cultural autonomies and communities (NCA and NCC) have been considered as traditional representatives of migrants in the dialogue with the authorities. Perhaps now it is impossible to find a single Russian region where these public organisations would not be considered by the authorities as representatives of migrant groups. A whole system of representation has been formed at the regional and federal levels, within the framework of which NCCs represent the interests of the 'diasporas' (Berg-Nordlie, Tkach, 2016: 181). However, as Galina Kalugina showed, the emergence of NCCs as representatives of migrants occurred not in the process of delegating by migrants to such organisations the right to represent their interests, but rather as a result of reconsidering the 'national issue' by the authorities, the framework of which included a new migration problem solving: "the contradictions between migrants and the local population were designated as national" (Kalugina, 2010: 93). It is indicative that already in the middle of the $2000 \mathrm{~s}$, ethnocultural and mi- 
gration discourses in the activities of the authorities (at least the municipal one closest to the problems 'on the ground') are considered as different ones (Kalugina, 2010: 104), but NCCs continue to fulfill their proposed function of representing the interests of migrants.

In this sense, NCCs are usually described using the term 'diasporas', as observed by V.I. Dyatlov in a situation of democratisation (in the understanding of Reinhart Koselleck) and suggesting "the institutional nature of the diaspora, its organised nature, membership, leadership, etc." (Dyatlov, 2017: 127). The basis for being described as a member of the diaspora is both migration experience and ethnicity in the primordialist sense. In other words, NCCs as 'diasporas' represent the interests of a group that is extremely blurred, the significant part of which does not have migration experience, or has it in a fairly distant past. The experience of interaction between authorities and 'leaders of diasporas' turned out to be more important here, which gives the first ones an opportunity to assign some responsibility for the actions of both the ethnic group and the 'migrants' assigned to it to NCCs, giving them symbolic power, and the latter to solve private issues in relations with power structures, often not related to migration issues (Berg-Nordlie, Tkach, 2016: 184). On the other hand, this approach allows to reproducing familiar ethnic categories not only in the description of migrants by the authorities and the media, but also in the self-descriptions of migrants. However, the big question remains whether the rhetoric of NCC leaders can be considered a form of self-description of any migrant groups.

An alternative to NCCs was public organisations of migrants, the largest of which is the Federation of Migrants of Russia (FMR), established in 2007. Created as an organisation of migrants and for migrants, one of its tasks on the official website, is "the formation of a positive image of a migrant in the minds of society". The right to speak about migrants and on their behalf is set not only in the goals and objectives of the organisation, but also through the publication of the monthly newspaper $\mathrm{Mi}$ grants Today. However, in the newspaper texts, migrants are present only as an object, deprived of a voice, and therefore require an external description:

"Migrants got to know a lot about traditional vacancies, such as cleaners, movers, pickers, and also got acquainted with vacancies for migrant women, for young people who speak Russian well and for qualified specialists" (Migrants Today, 2019, December, p. 2). Here migrants turn out to be listeners, not speakers; words and meanings are not produced by them, and even, which is characteristic, not on their behalf, but for them.

An attempt to give the floor to the migrant is the FMR project "Migrant Stories". Built as a video interview with migrants in various situations, the project really brings the migrant to communication with the audience. However, such communication is, firstly, mediated by the figures of the interviewer and director, determining the content and presentation of the video, and secondly, one-sided, since the reaction of the audience does not imply any feedback.

Migrants find themselves in the same position in the publications of "News of Labour Migration" - "an organ of the Central Committee of the Trade Unions of Migrant Workers" ${ }^{1}$ : migrants here are almost faceless masses, in whose interests the organisation acts. Migrants themselves in the texts of the site are more likely an audience than a subject of communication. A representative example of the programmes of the weekly seminar conducted by this organisation is: lows

"The programme of the seminar is as fol-

- coverage of issues related to the migration legislation of Russia, innovations in the legislation;

- questions of migrants and, accordingly, answers to all the most acute problems, analysis of situations;

- speeches for migrants delivered by trade union specialists, lawyers, invited experts". ${ }^{2}$

For all the variety of publications of such organisations, their rhetoric is united by a sim-

\footnotetext{
1 Migrant Labour Union, available at: http://www.profmigr. com/index.php (03.04.2020)

2 Seminar for migrants in the office of the Migrant Labour Union, available at: http://www.profmigr.com/index. php?option $=$ com_content\&task $=$ view\&id $=1351 \&$ Itemid $=2$ (03.04.2020)
} 
ilar position of migrants: they are either an object of descriptions or an audience. In both cases they are represented as an almost completely depersonalised mass, not speaking in its own name. This is probably a natural consequence of the creation of organisations offering a vertical system of relations in one form or another. The delegated or assigned right to speak on behalf of migrants deprives them of subjectivity in communication.

Migrant electronic social media become a living organ producing the self-description language of migrants as direct speech. Forming as horizontal networks with applied tasks - the search for a solution to situational problems through an appeal to collective experience (see, for example, Timoshkin, 2019), migrant online forums have become self-presentation mechanisms. It is here that the migrant acquires subjectivity as a participant in the polylogue: in posts or comments on them, the discussion participants speak about themselves and on their own behalf. Outlining their stories with purely pragmatic goals (exploring opportunities, finding a solution to a problem, etc.), the migrants set out their story, their interests and intentions, creating a self-portrait of a particular person. Similarly, in the descriptions, personality traits are also acquired by representatives of the host society - officials, employers, and common people. Arising in the network ad hoc with the function of interaction's nodes, such resources are formed as a collective text, in which there is no single author or interpreter, and only a moderator can be a director who monitors compliance with the rules of the resource.

In this sense, the key difference between descriptions and self-descriptions of migrants produced in migrant social media is their personification. They contain the image of migrants as a group formed through a description of specific individuals, as opposed to other sources, where the characteristics of the group are extrapolated to each of its representatives. In a broader perspective, it is here that the humanisation as a whole of a rather successfully dehumanised image of a migrant takes place.

Migrant YouTube channels are becoming a new and so far extremely weakly reflected in the academic text method of self-description of migrants. Having appeared quite recently, this phenomenon, however, has rapidly turned into a vast array of data on migrants and their interactions with host communities and the state. This source remains highly underestimated by researchers, despite the fact that, it is actually a slightly open door to a closed field. If in ordinary situations the researcher requires extraordinary efforts to get into this field as a "friendlies", and even more so, in the format of the included observation, then such channels, in fact, allow the anthropologist to see the behind-the-scenes life of migrant communities that are adapting in the country and region of arrival. The video content through 'online observation' (Roser, 2011) allows the researcher to be involved in "the inner working" of the adaptation process, reflecting both the details of interaction with government agencies and a wide range of everyday details of adaptation to the realities of the host country and region.

A retrospective analysis (Bassi et al., 2019) of comments on videos and video channels in general allows us to observe the process of interaction between new comers (or those just planning to migrate to Russia) with migrant communities adapted in the host country. In a broader sense, they allow to see the processes of building the interaction of new comers with migrant networks and the use of collective experience to build individual migration paths. These processes are fixated here as plots for individual videos, discussions, ratings, links to other, including online and offline migrants' resources. Reconstruction of the processes of building such relationships allows to us see a system of relations, which often remains hidden from a researchers, even they having gained the access to the closed area.

Working as a tool for constructing individual migration paths and adaptation scenarios, video channels also become an important mechanism for the formation of social capital. The authors of such channels not only create entry points for a migrant in horizontal networks and the opportunity to join the collective experience. They not only show the real 
life and problems of migrants, but also form the language that migrants speak with the host society. They (the authors of migrant YouTube channels) produce language and meanings that are relevant to the collective and personal experience of migrants, and, at the same time, understandable (or at least accessible to understanding) to representatives of the host society. As a result, such migrant video bloggers become mediators not only between newly arrived migrants and migrant groups adapted in Russia, but also between migrants and host communities.

The role of a mediator, which the authors of such video channels begin to take de facto, on the one hand, turns out to be less noticeable in everyday life: they are not included in the direct social interactions of migrants, as a result of which the opportunities for 'cashing out' social capital are not great. However, on the other hand, the role of the author of words and meanings turns them into a body that accumulates collective experience and speaks on their behalf, which opens less obvious, but larger-scale opportunities for the realisation of social capital.

One of the most important options for its use is the opportunity and the right to speak on behalf of migrants. The appearance of such "network" figures, entitled to represent migrants as broad communities, is almost more significant than the formation of a channel for transmitting the collective experience of a group (migrants) for newcomers. The emergence, albeit in the future, of an alternative to the "leaders of diasporas" (Dyatlov, 2017) gives a chance to change the group view of migrants to an individual, and therefore the opportunity to return the migrant's personality to the discourses of the host society.

It is also important that the privatisation of the right to speak on behalf of migrants takes place here without the transfer of an 'exclusive license'. The right to speak on behalf of migrants is not institutionalised for video bloggers 'from above', as is the case with NCC leaders, but is rather "bottom up". It is determined not by a complex system of relations within NCCs, which is ambiguous not only to an outside observer, but also to members of migrant com- munities, but by the number of views, likes and dislikes - a system that is noticeably more transparent and verifiable. The verification tool also becomes the amount of comments under the video, which directly or indirectly confirms not only the authenticity of the broadcast experience, but also its applicability in similar situations.

It should be emphasised that the language of many migrant channels is Russian. This is not only its setting as a lingua franca and a communication strategy that ensures successful interaction with migrant networks that are different in the country of origin, mother tongues, occupation and regions of residence. This means that the Russian language confidently entrenched itself not only in the Internet space, but in the everyday life of traditional migrant places: markets, construction sites, catering establishments (Grigorichev, Guzey, 2017). Russian-language migrant You-Tube channels also become a tool for constructing a mutual description language, which is offered on behalf of migrants to the host community. In fact, this is an attempt to present migrants beyond the reality of official media, bringing the description of migrants beyond the stereotypical representations of the media and social media to the plane of individual interactions. In a way, this is an attempt to deconstruct the migrant's media image and transfer it from the group to the human dimension. It is important to note here that on some migrant YouTube channels such a premise is present directly, as a disclaimer, either as a whole channel or for individual stories, which suggests the reflexive nature of the construction of migrants' self-description language for the host society.

Migrant YouTube channels are becoming not an alternative, but rather an important addition to the 'migrant' cinema, the most striking example of which in recent years has been the drama "Ayka" (2018, directed by S. Dvortsevoy). Even though the created images are quite acute, this and other films remain examples, rather, of art-house cinema, and therefore are focused on fairly narrow groups of 'intelligent viewers'. The target audience of migrant video channels, by contrast, is as broad as possible and claims to cover, if not 
the entire host society, then a significant part of it that is encountered in everyday interactions and which, importantly, lives on close stories and problems.

$$
* * *
$$

It can be stated that today in Russia the languages for mutual description of the host society by migrants and migrants by the host society appear to be quite different. Despite more than thirty years of interaction experience and undoubtedly the existing dynamics (which requires at least an independent article), up to this day in Russia there has still not been a more or less stable consensus of mutual representations and descriptions. Moreover, we can confidently say that the host society is not at all familiar with the language of migrants, which they use to describe themselves and the communities of the country and the region of arrival. This creates the image of parallel worlds, not inter- secting realities, aliens from which are almost as far apart from each other as a foreigner from the Soviet citizen.

At the same time, everyday practices demonstrate the inclusion of migrants in the joint use of urban infrastructure with their host communities and even its formation. The common of space encourages to search for a language of mutual description, its development in the process of everyday contacts. It can be assumed that this process is more productive at a horizontal level in the process of folding informal networks, both migrant and mixed, than in a dialogue between authorities and representatives of migrants, whose legitimacy is guaranteed by authorities, and not by ordinary members of the group. The language of social media in this perspective is not only another field for the researcher, but also a good platform for finding the language of mutual descriptions.

\section{References}

Bassi, H., Lee, C.J., Misener, L. \& Johnson, A.M. (2019). Exploring the characteristics of crowdsourcing: An online observational study. In Journal of Information Science, 1-22.

Bauman, Z. (2008). Tekuchaia sovremennost' [Liquid Modernity]. Saint Petersburg, Piter.

Berg-Nordlie, M., Tkach, O. (2016). You are responsible for your people. The role of Diaspora leaders in the governance of immigrant integration in Russia. In Demokratizatsiia: The Journal of Post-Soviet Democratization, 2 (24), 173-198.

Brubaker, R. (2012). Etnichnost' bez grupp [Ethnicity Without Groups]. Moscow, Higher School of Economics Publishing House, 408 p.

Bryazgina, D.E., Dzhanyzakova, S.D., Nam, I.V., Sadyrin, A.A. \& Smetanin, F.A. (2019). Trudovye migranty iz Tsentral'noi Azii v sibirskom gorode: infrastruktura, zaniatost', povsednevnost', dosug [Migrant workers from central Asia in a Siberian city: infrastructure, employment, everyday life and leisure]. In Demograficheskoe obozrenie [Demographic Review], 4 (6), 31-52.

Dyatlov, V.I. (2010). Transgranichnye migranty v sovremennoi Rossii: dinamika formirovaniia stereotipov [Cross-border migrants in modern Russia: dynamics of stereotypes development]. In Politiia, 3-4, 121-149.

Dyatlov, V.I. (2017). "Vchera gubernator vstrechalsia s diasporami...”. Prikliucheniia termina i poniatiia v sovremennoi Rossii ["Yesterday the governor met the diasporas." Adventures of the term and concept in the modern Russia]. In Migratsionnyi krizis: mezhdunarodnoe sotrudnichestvo i natsional'nye strategii: sbornik nauchnykh statei [Migration crisis: international cooperation and national strategies: collection of scientific articles]. Moscow, Delo RANKHiGS Publishing House, 123-134.

Dyatlov, V.I. (ed.) (2009). Transgranichnye migratsii i prinimaiushchee obshchestvo: mekhanizmy $i$ praktiki vzaimnoi adaptatsii [Trans-border migrations and the host society: mechanisms and practices of mutual adaptation]. Ekaterinburg.

Filippova, E.V. (2019). Uskol'zaiushchaia 'etnichnost', Retsenziia na knigu 'Sotsial'nye factory mezhetnichekoi napriazhennosti v Rossii’ [Elusive ethnicity]. In Demograficheskoe obozrenie [Demographic Review], 2 (6), 202-208. 
Goffman, E. (2000). Predstavlenie sebia drugim v povsednevnoi zhizni [The Presentation of Self in Everyday Life]. Moscow, Kuchkovo pole.

Grigorichev, K. (2018). Restructuring of the Chineseness: Ethnic marking of city spaces in the light of migration from China. In Journal of Siberian Federal University. The Humanities, 11 (11), 1762-1775.

Grigorichev K.V., Guzey Ia.S. (2017). Iazyk "etnicheskogo" rynka: Bazar kak pidgin I situatsia granitsy. [The language of "ethnic" markets: bazaar as a pidgin and situation of border]. In Vestnik Rossiiskogo Universiteta Druzhby Narodov-Seriya lingvistika-Russian Journal of Linguistics, 21(3), 530-556

Kalugina, G.V. (2010). Mestnaia vlast' i transformatsiia diskursa 'natsional'noi politiki' v postsovetskuiu epokhy (sluchai Irkutska) [Local authorities and transformation of 'national policy' discourse in the Post-Soviet era (Irkutsk case). In Politiia, 2, 91-106.

Kiseleva, I.G., Damberg, S.V. (2001). 'Drugie russkie': rol' v istoricheskom siuzhete ['Other Russians': the role in the historical plot]. Vestnik Evrazii [Bulletin of Eurasia], 3, 22-46.

Luhmann, N. (2005). Real'nost' massmedia [The Reality of the Mass Media]. Moscow, Praksis (Die Realität der Massenmedien (= Nordrhein-Westfälischen Akademie der Wissenschaften, Vorträge G 333), Opladen 1995; second, extended edition 1996).

Roser, B-M. (2011). Ethnography goes online: towards a user-centred methodology to research interpersonal communication on the internet. In Qualitive research, 11(6), 716-735.

Rotar', I. (2001). Chuzhie russkie [Other Russians]. In Nezavisimaia gazeta [Independent Newspaper]. Available at: http://www.ng.ru/cis/2001-06-\%2006/5_russian.html

Simmel, G. (2008). Ekskurs o chuzhake [Excursus about a stranger]. In Sorsiologicheskaia teoriia: istoriia, sovremennost', perspektivy [Sociological theory: history, modernity, perspectives]. Saint Petersburg, Vladimir Dal', 9-14.

Timoshkin, D.O. (2019). Tema snizheniia izderzhek na legalizatsiiu v prinimaiushchei strane: obsuzhdenie $\mathrm{v}$ russkoiazychnykh migrantskikh internet-soobshchestvakh [Reducing legalization expenses as a topic in russian-speaking migrant online communities]. In Sotsiologichekii zhurnal [Sotsiologicheskiy Zhurnal], 4 (25), 56-71.

Tishkov, V.A. (2016). Ot etnosa k etnichnosti i posle [From ethnic group to ethnicity and after]. In Etnograficheskoe obozrenie [Ethnographic Review], 5, 5-22.

Vitkovskaya, V. (1999). Vynuzhdennaia migratsiia i migrantofobiia v Rossii [Forced migration and migrant phobia in Russia]. In Neterpimost'v Rossii: starye i osnovnye fobii [Intolerance in Russia: old and key phobias]. Moscow. 


\title{
Принимающее общество и мигранты: \\ в поисках языков взаимных описаний
}

\author{
К.В.Григоричева, \\ ${ }^{a}$ Иркутский государственный университет \\ Российская Федераџия, Иркутск \\ ${ }^{6}$ Национальный исследовательский \\ Томский государственный университет \\ Российская Федерачия, Томск \\ ${ }^{6}$ Сибирский федеральный университет \\ Российская Федерачия, Красноярск
}

\begin{abstract}
Аннотация. Статья открывает подборку исследований, посвященных проблеме выработки языков взаимного описания мигрантов и принимающего общества. Авторы рассматривают поставленную проблему, с одной стороны, через призму неоднородности языка описания мигрантов в принимающем обществе, а с другой через отсутствие легитимных представителей мигрантов, представляющих их в диалоге с российским обществом. Предлагается взгляд на причины доминирования этнического дискурса в описании мигрантов и миграционной ситуации и широкого плюрализма в использовании этнических категорий при описании миграции. Показывается, что мигранты не принимают участия в выработке риторики организаций, признаваемых властью в качестве их легитимных представителей. Ставится вопрос о формировании новых представителей мигрантских групп, чья легитимность опирается не на полномочия, делегированные властью, а на признание горизонтальными сообществами. Предполагается, что на основе сетевых репрезентаций происходит формирование механизма гуманизации образа мигрантов через возвращение им субъектности в коммуникации с принимающим обществом.
\end{abstract}

Ключевые слова: языки описания, принимающее общество, мигранты, этничность, горизонтальные сети, YouTube.

Исследование выполнено при поддержке Российского научного фонда, проект № 18-18-00293.

Научная специальность: 22.00.00 - социологические науки. 